

Open Access 0 Subscription or Fee Access

\section{CROSS-CULTURAL VALIDATION AND PSYCHOMETRIC EVALUATION OF THE SELF- MEDICATION ASSESSMENT TOOL (SMAT) FOR ASSESSING AND OPTIMIZING MEDICATION THERAPY MANAGEMENT OF OLDER PEOPLE}

Ana Margarida Advinha, Carla Teixeria de Barros, Maria Pereira Guerreiro, Carla Nunes, Manuel José Lopes, Sofia de Oliveira-Martins

\begin{abstract}
Background, rationale and objectives: The assessment of medication management ability in the elderly can be performed using specific tools, such as the Self-Medication Assessment Tool, which considers real and simulated regimens. The objective of this study was to perform the linguistic and cultural adaptation of the Self-Medication Assessment Tool to European Portuguese and determine its psychometric properties.
\end{abstract}

Methods: The adaptation commenced with the translation/back translation cycle completed by 4 independent bilingual experts. The cultural component was accomplished through an external expert meeting and a longitudinal screening of concepts and construct. The pilot study was carried out in a sample of 150 Portuguese community-dwelling elders. Descriptive data, correlations, internal reliability, response consistency and exploratory factor analysis was conducted using SPSS Statistics (v22).

Results: The pilot study was carried out in a sample of 150 community-dwelling elders: 112 $(74.7 \%)$ participants were women; mean age was $74.73 \pm 6.43$ years. The Self-Medication Assessment Tool (Portuguese version) standard regimen (simulated medication regimen) mean scores were $20.92 \pm 6.83$ in functional ability and $38.75 \pm 5.92$ in cognitive ability; the real regimen (medication taken by the elderly) mean scores were $83.74 \pm 15.86$ in medication recall, $96.96 \pm$ 11.39 in adherence self-report and $4.82 \pm 10.1$ in intentional non-adherence. Cronbach's $\alpha$ were 0.87 (functional ability), 0.84 (cognitive ability), 0.57 (medication recall), 0.94 (adherence self-report) and 0.79 (intentional non-adherence). The response consistency between test and re-test was verified.

Conclusions: We have developed the European Portuguese version of the Self-Medication Assessment Tool with acceptable psychometric properties which can now be employed in the study of the elderly in clinical and research contexts.

\section{KEYWORDS}

Aged, complex medication regimens, coping strategies, cross-validation, geriatric assessment, medication adherence, medication therapy management, person-centered healthcare, polypharmacy,
OPEN JOURNAL
SYSTEMS

Journal Help

USER

Username $\lcm{ }$

Remember me

Login

SUBSCRIPTION

Login to verify

subscription

NOTIFICATIONS

View

Subscribe

JOURNAL

CONTENT

Search

Search Scope
All
Search

Browse

By Issue

By Author

By Title

Other Journals

FONT SIZE

INFORMATION

For Readers

For Authors

For Librarians 


\section{FULL TEXT:}

PDF

\section{REFERENCES}

Farrell, B., Shamji, S., Monahan, A. \& French Merkley, V. (2013). Reducing polypharmacy in the elderly: Cases to help you "rock the boat." Canadian Pharmacists Journal 146 (5) 243-244.

Mortazavi, S.S., Shati, M., Keshtkar, A., Malakouti, S.K., Bazargan, M. \& Assari, S. (2016). Defining polypharmacy in the elderly: a systematic review protocol. BMJ Open 6 (3) e010989.

Fulton, M.M. \& Allen, E.R. (2005). Polypharmacy in the elderly: a literature review. Journal of the American Academy of Nurse Practioners 17 (4) 123-132.

Hammond, T. \& Wilson, A. (2013). Polypharmacy and falls in the elderly: a literature review. Nursing and Midwifery Studies 2 (2) 171-175.

Maher, R., Hanlon, J. \& Hajjar, E. (2014). Clinical Consequences of Polypharmacy in Elderly. Expert Opinion on Drug Safety 13 (1). doi: 10.1517/14740338.2013.827660.

Veehof, L.J., Jong, B.M. \& Haaijer-Ruskamp, F. (2000). Polypharmacy in the elderly - a literature review. European Journal of General Practice 6 (3) 98-106.

Elliot, R.A. \& Marriott, J.L. (2009). Standardised assessment of patients' capacity to manage medications: a systematic review of published instruments. BMC Geriatrics 9, 27.

Widham, B., Griswold, M., Fried, L., Rubin, G., Xue, Q. \& Carlson, M. (2005). Impaired vision and the ability to take medications. Journal of the American Geriatrics Society 53 (7) 1179-1190.

Notenboom, K., Beers, E., Van Riet-Nales, D.A., Egberts, T.C.G., Leufkens, H.G.M., Jansen, P.A.F. \& Bouvy, M.L. (2014). Practical problems with medication use that older people experience: A qualitative study. Journal of the American Geriatrics Society 62 (12) 2339-2344.

Maddigan, S.L., Farris, K.B., Keating, N., Wiens, C.A. \& Johnson, J.A. (2003). Predictors of older adults' capacity for medication management in a self-medication program: a retrospective chart review. Journal of Aging and Health 15 (2) 332-352.

Beckman, A.G.K., Parker, M.G. \& Thorslund, M. (2005). Can elderly people take their medicine? Patient Education and Counseling 59 (2) 186-191.

Tordoff, J., Simonsen, K., Thomson, W.M. \& Norris, P.T. (2010). "It's just routine.” A qualitative study of medicine-taking amongst older people in New Zealand. Pharmacy World \& Science 32 (2) 154-161.

Beckman, A., Bernsten, C., Parker, M.G., Thorslund, M. \& Fastbom, J. (2005). The difficulty of opening medicine containers in old age: a population-based study. Pharmacy World \& Science 27 (5) 393-398.

Edelberg, H.K., Shallenberger, E. \& Wei, J.Y. (1999). Medication management capacity in highly functioning community-living older adults: detection of early deficits. Journal of the American Geriatrics Society 47 (5) 592-596.

Edelberg, H.K., Shallenberger, E., Hausdorff, J.M. \& wei, J.Y. (2000). One-year follow-up of medication management capacity in highly functioning older adults. Journals of Gerontology. Series A, Biological Sciences and Medical Sciences 55 (10) M550-M553.

Patterson, T.L., Lacro, J., McKibbin, C.L., Moscona, S., Hughs, T. \& Jeste, D.V. (2002). Medication management ability assessment: results from a performance-based measure in older outpatients with schizophrenia. Journal of Clinical Psychopharmacology 22 (1) 11-19.

Hutchison, L., Jones, S., West, D. \& Wei, J.Y. (2006). Assessment of medication management by community-living elderly persons with two standardized assessment tools: A cross-sectional study. American Journal of Geriatric Pharmacotherapy 4 (2) 144-153.

Irvine-Meek, J.M. \& Gould, O.N. (2011). Psychometric evaluation of a self-medication assessment tool in an elderly population. Canadian Journal of Hospital Pharmacy 64 (1) 16-24.

Irvine-Meek, J., Gould, O.N., Wheaton, H. \& Todd, L.E. (2010). Acceptability and Face Validity of a Geriatric Self-Medication Assessment Tool. Canadian Journal of Hospital Pharmacy 63 (3) 225232.

Sousa, V.D. \& Rojjanasrirat, W. (2011). Translation, adaptation and validation of instruments or scales for use in cross-cultural health care research: a clear and user-friendly guideline. Journal of Evaluation in Clinical Practice 17 (2) 268-274.

Streiner, D.L. \& Norman, G.R. (2008). Health Measurement Scales: A practical guide to their development and use. 4th Edn. Oxford: Oxford University Press.

Nunnally, J.C. \& Bernstein, I.H. (1994). Psychometric Theory. 3rd Edn. New York: McGraw-Hill.

Anthoine, E., Moret, L., Regnault, A., Sébille, V. \& Hardouin, J.B. (2014). Sample size used to validate a scale: a review of publications on newly-developed patient reported outcomes measures. 

Health and Quality of Life Outcomes 12, 176.

Abdi, H. (2003). Factor rotations in factor analyses. In: Encyclopedia of social sciences research methods. Lewis-Beck, M., Bryman, A. \& Futing, T. (Eds.). Thousand Oaks, CA: Sage.

Brown, J.D. (2009). Choosing the right type of rotation in PCA and EFA. Shiken: JALT Testing \& Evaluation SIG Newsletter. 13 (3) 20-25.

Marôco, J. (2014). Análise Estatística com o SPSS Statistics. 6th Edn. Report Number May 2014.

Kristensen, S., Sabroe, S., Bartels, P., Mainz, J. \& Christensen, K.B. (2015). Adaption and validation of the Safety Attitudes Questionnaires for the Danish hospital setting. Clinical Epidemiology 7, 149160.

Tavakol, M. \& Dennick, R. (2011). Making sense of Cronbach's alpha. International Journal of Medical Education 2, 53-55.

Kaiser, H.F. (1958). The varimax criterion for analytic rotation in factor analysis. Psychometrika 23 (3) $187-200$.

Khagram, L., Martin, C.R., Davies, M.J. \& Speight, J. (2013). Psychometric validation of the SelfCare Inventory-Revised (SCI-R) in UK adults with type 2 diabetes using data from the AT.LANTUS Follow-on study. Health and Quality of Life Outcomes 11, 24.

Perneger, T.V., Leplège, A. \& Etter, J.F. (1999). Cross-cultural adaptation of a psychometric instrument: two methods compared. Journal of Clinical Epidemiology 52 (11) 1037-1046.

\section{REFBACKS}

- There are currently no refbacks. 